\title{
PRODUKTIVITAS KERJA KARYAWAN DIPENGARUHI OLEH PENILAIAN PRESTASI KERJA, KEPEMIMPINAN, PENDIDIKAN, MASA DINAS DAN JENJANG PEKERJAAN PADA PT. CENTRALPERTIWI BAHARI FEED MILL OPERATION DI LAMPUNG
}

\author{
Zaenal Arifin \\ Program Studi Teknik Industri, Sekolah Tinggi Teknologi Nusantara Lampung, \\ Jl. Pulau Damar Gg. Sapta Marga Kelurahan Waydadi Baru Kecamatan Sukarame \\ Kota Bandar Lampung \\ E-mail: zaenal.arifin7802@gmail.com
}

\begin{abstract}
This research aimed at finding out whether the performance appraisal, education, length of service and work rank simultaneously or partially influenced employee's productivity at PT. CPB. Performance appraisal, leadership, education, length of service and work rank simultaneously gave positive and significant influence towards employee's productivity at PT. CPB. Employee's productivity at PT. CPB was determined by performance appraisal, leadership, education, length of service and work rank. Employee's productivity at PT. CPB was significantly influenced by performance appraisal. Employee's productivity at PT. CPB was significantly influenced by leadership. Employee's productivity at PT. CPB was significantly influenced by education. Employee's productivity at PT. CPB was significantly influenced by length of service. Employee's productivity at PT. CPB not influenced by work rank. The performance appraisal had a major influence on employee's productivity at PT. $C P B$ which was proved by the high score of regression coefficient of performance appraisal variable (0.963), higher than the regression coefficient of leadership variable (0.538), higher than regression coefficient of education variable (0.009), higher than regression coefficient of length of service variable (0.011), and higher than regression coefficient of work rank variable at (0.010).
\end{abstract}

Keywords: Leadership, Productivity, Work performance.

\section{Pendahuluan}

Situasi dan kondisi persaingan usaha semakin ketat dan perubahan lingkungan bisnis yang berubah sangat cepat, kedudukan sumber daya manusia yang memiliki keunggulan kompetitif semakin diperhitungkan. Perusahaan yang ingin membangun persaingan melalui karyawannya sebagai sumber keunggulan kompetitif harus menerapkan suatu sistem penilaian (appraisal) untuk meningkatkan prestasi kerja karyawannya. Penilaian prestasi kerja akan menilai kontribusi karyawan kepada perusahaan selama periode waktu tertentu. Dampak prestasi kerja memungkinkan karyawan mengetahui seberapa baik karyawan yang bersangkutan bekerja. Penilaian prestasi kerja merupakan proses yang berbeda dari evaluasi pekerjaan. Penilaian prestasi kerja berkenaan dengan seberapa baik seorang karyawan melakukan pekerjaan yang diberikan atau ditugaskan, sedangkan evaluasi pekerjaan menentukan seberapa tinggi harga sebuah pekerjaan atau dengan kata lain berapa gaji yang pantas untuk pekerjaan tersebut. Penilaian prestasi kerja dilakukan untuk memotivasi karyawan dan juga sebagai 
cara untuk memonitor prestasi kerja karyawan.( Gary Dessler, 2006).

Mempertimbangkan kutipan di atas kita dapat melihat bahwa motivasi karyawan akan mempengaruhi produktivitas kerja karyawan tersebut. Sesuai dengan pengamatan dan hasil wawancara penulis dengan beberapa orang yaitu 1 orang manager, 2 orang Ka. Sie dan 5 orang operator karyawan PT. Centralpertiwi Bahari bahwa produktivitas kerja karyawan menunjukkan gejala-gejala sebagai berikut: 1.Masih adanya karyawan belum dapat menyelesaikan tugas dengan cepat dan tepat; 2. Masih adanya karyawan belum dapa bekerja secara kreatif dan inovatif; 3. Masih adanya karyawan masih tergantung pada atasan dalam bekerja; 4 . Masih adanya karyawan belum mempunyai andil yang lebih dari yang diharapkan; 5. Masih adanya karyawan belum mampu mencapai standar kerja yang diharapkan; 6. Masih adanya karyawan belum dapat memberikan pelayanan yang dapat memuaskan konsumen. Berdasarkan permasalahan di atas, maka dapat dirumuskan bahwa produktivitas kerja karyawan pada PT.Centralpertiwi Bahari Feed Mill Operation dipengaruhi oleh penilaian prestasi kerja, dipengaruhi oleh kepemimpinan, dipengaruhi oleh pendidikan, dipengaruhi oleh masa dinas dan dipengaruhi oleh jenjang pekerjaan. Menganalisis pengaruh penilaian prestasi kerja, kepemimpinan, pendidikan, masa dinas dan jenjang pekerjaan pada produktivitas kerja karyawan pada PT.Centralpertiwi Bahari Feed Mill Operation. Melakukan identifikasi variabel yang paling berpengaruh pada produktivitas kerja karyawan pada PT.Centralpertiwi Bahari Feed Mill Operation.

\section{Pengertian Penilaian Prestasi kerja.}

Penilaian prestasi kerja karyawan dalam pelaksanaan pekerjaan secara keseluruhan yang menyangkut berbagai bidang seperti kemampuan kerja, kerajinan, disiplin, hubungan kerja atau hal-hal khusus sesuai dengan bidang dan level pekerjaan yang di jabatnya.
Penilaian kinerja merupakan membandingkan prestasi aktual karyawan dengan prestasi kerja dengan yang diharapkan darinya (Dessler 2004: 87). Menurut Dessler ada 5 ( lima) faktor dalam penilaian kinerja yang populer yaitu: 1 Kehadiran, meliputi : regularitas, dapat dipercayai/diandalkan dan tepat waktu. 2. Supervisi yang diperlukan, meliputi : membutuhkan saran, arahan atau perbaikan. 3. Kuantitas pekerjaan, meliputi : volume keluaran dan kontribusi. 4. Kualitas pekerjaan, meliputi : akurasi, ketelitian, pemampilan dan penerimaan keluaran. 5. Konservasi, meliputi : pencegahan pemborosan, kerusakan dan pemeliharaan peralatan.

Proses

\section{Penilaian Prestasi Kerja}

Proses penilaian prestasi kerja secara fundametal meliputi tiga kegiatan yaitu identifikasi (identification), pengukuran (measurement) dan pengelolaan (management). Identifikasi merupakan langkah pertama dalam melakukan pengukuran atau penilaian atas prestasi kerja karyawan, yaitu penentuan mengenai pekerjaan atau bidang kerja apa saja yang akan dinilai. Secara rasional analisis jabatan merupakan dasar bagi sistem pengukuran prestasi kerja karena melalui analisis jabatan ini dapat ditentukan deskripsi tugas dan spesifikasi jabatan dari suatu jabatan yang menjadi tanggung jawab karyawan dalam suatu perusahaan. Aspek-aspek yang diidentifikasi sebagai ruang lingkup kerja karyawan harus relevan dengan uraian tugas dari suatu jabatan, oleh karena itu sistem penilaian harus terfokus pada prestasi kerja yang mempengaruhi kesuksesan perusahaan yang sesuai dengan deskripsi jabatan.

\section{Kepemimpinan}

$$
\text { Menurut Handoko }
$$

kepemimpinan diartikan sebagai proses mempengaruhi orang lain agar bekerja keras menyelesaikan tugas-tugas penting. Berdasarkan definisi ini seorang pemimpin tim (tim leader) berfungsi menggerakkan anggota tim untuk menyelesaikan tugas-tugas tim dengan kewenangan sesuai level otonomi yang diberikkan, pemimpin bertanggung jawab 
terhadap tiga hal yang saling terkait yaitu : pencapaian tugas, membangun dan mempertahankan tim dan pengembangan individu.

\section{Produktivitas}

Produktivitas secara filosofi mengandung arti keinginan dan usaha setiap manusia untuk selalu meningkatkan mutu kehidupan dan penghidupannya. Kehidupan hari ini harus lebih baik dari hari kemarin, dan kehidupan hari esok harus lebih baik dari hari ini, adalah juga pandangan yang memberi semangat pada produktivitas. Pandangan yang cenderung filosofis tersebut memberi arti dan semangat yang cukup mendalam, dan memungkinkan setiap orang yang memahaminya memandang kerja, baik secara individual maupun berkelompok dalam suatu organisasi sebagai suatu keutamaan. Mengutamakan bekerja dengan mengacu pada unsur efisiensi dan efektivitas sebenarnya juga sudah merupakan penjabaran secara teknis tentang konsep produktivitas.

\section{Metodologi Penelitian}

Peneliti melakukan penelitian dengan mengambil lokasi atau obyek penelitian di PT.Centralpertiwi Bahari Feed Mill Operation Kawasan Industri Lampung, Kec. Tanjung Bintang, Kab.Lampung Selatan, Propinsi Lampung.

\section{Metode Pengukuran Instrumen}

Data skor instrumen dapat diandalkan apabila instrumen tersebut memiliki validitas dan reliabilitas. Hal ini berkaitan dengan uji kesahihan dan konsistensi dari instrumen penelitian.

\section{Uji Validitas}

Validitas didefinisikan sebagai ukuran seberapa cermat suatu pengukuran melakukan fungsi ukurannya. Suatu instrumen dinyatakan sahih bila instrumen tersebut mampu mengukur apa saja yang hendak diukurnya. Uji validitas yang digunakan dalam penelitian ini adalah construct validity (logical validity). Proses validasi instrumen penelitian adalah sebagai berikut : (a) menyusun instrumen pengumpulan data berdasarkan logika dari definisi operasional variabel penelitian, (b) berdasarkan definisi operasional tersebut ditentukan indikatorindikator variabel dan disusun item pertanyaan, (c) menerapkan atau uji coba pada sasaran terhadap 15 responden di PT. Centralpertiwi Bahari Feed Mill Operation.

\section{Uji Reliabilitas}

Reliabilitas menunjukkan sejauh mana pengukuran itu dapat memberikan hasil yang relatif tidak berbeda bila dilakukan pengukuran kembali terhadap subyek yang sama. Reliabilitas menyangkut masalah akurasi, konsistensi dan stabilitas alat ukur. Maksud menguji reliabilitas adalah untuk melihat tingkat konsistensi instrumen Apakah hasilnya akan tetap reliable bila diterapkan kepada kelompok subyek itu kembali dalam waktu yang berbeda.

Beberapa teknik untuk menguji reliabilitas instrumen dapat dilakukan dengan dua cara yaitu : a) Repeated Measure atau pengukuran ulang. Se seorang akan disodori pertanyaan yang sama pada waktu yang berbeda, dan kemudian dilihat apakah ia tetap konsisten dengan jawabannya, b) One Shot atau pengukuran sekali. Pengukuran hanya sekali dan kemudian hasilnya dibandingkan dengan pertanyaan lain atau mengukur korelasi antar jawaban pertanyaan. (Ghozali, 2018).

Dalam penelitian ini pengujian reliabilitas instrumen dilakukan dengan prosedur yang kedua yaitu dengan menggunakan cara One Shot. Program SPSS memberikan fasilitas untuk mengukur reliabilitas dengan uji statistic Cronbach Alpha $(\alpha)$. Suatu variabel dikatakan reliable jika memberikan nilai Cronbach Alpha ( $\alpha)$. > 0,60 (Ghozali, 2018).

\section{Sampel dan metode sampling}

Populasi merupakan seluruh individu yang menjadi subyek penelitian. Populasi dalam penelitian ini adalah seluruh karyawan yang bekerja di PT. Centralpertiwi Bahari, yang terdiri dari 177 karyawan dengan perincian karyawan tetap sebanyak 96 orang dan karyawan harian lepas sebanyak 81 orang. Untuk 
mengolah data hasil penelitian yang telah dilakukan tabulasi dalam bentuk Tabel, guna memperoleh gambaran kemudian dianalisis secara deskriptif maupun secara statistik. Analisa ini dilakukan berdasarkan data yang akan dikumpulkan dari pertanyaan yang telah diajukan dan diisi oleh responden ( PT. Centralpertiwi Bahari Feed Mill Operation). Teknik analisis deskriptif persentase digunakan untuk mengetahui jawaban responden terhadap skor ideal yang seharusnya, dengan rumusan sebagai berikut :

\section{$\Sigma$ SR \\ $P=\longrightarrow 100 \%$ $\Sigma$ SI}

Dimana :

$\mathrm{P}=$ Prosentase yang ingin diketahui

$\Sigma$ SR = Jumlah skor responden yang didapat

$\Sigma$ SI = Jumlah skor yang seharusnya diperoleh

Jumlah skor ideal ( $\Sigma$ SI ) diperoleh dari perkalian jumlah item pertanyaan dikali skor tertinggi dikali jumlah responden.

Setelah diketahui hasil presentase, langkah selanjutnya adalah menentukan kategori hasil sebagai berikut :

$\begin{array}{lll}81 \%-100 \% & : & \text { Baik sekali } \\ 66 \%-80 \% & : & \text { Baik } \\ 51 \%-65 \% & : & \text { Cukup } \\ 35 \%-50 \% & : & \text { Kurang } \\ <35 \% & : & \text { Kurang sekali }\end{array}$

Analisis desktiptif persentase belum akan mampu menjawab pertanyaan penelitian, karena hanya dapat mengetahui perbandingan jawaban responden atas skor ideal. Untuk itu perlu dilakukan analisis regresi.

\section{Uji Autokorelasi}

Fenomena adanya autokorelasi dalam data yang dianalisis dapat dilakukan dengan menggunakan DurbinWatson Test (DW-Test), dimana jika hipotesis $\mathrm{Ho}$ adalah tidak ada autokorelasi dan hipotesis $H i$ terdapat autokorelasi, maka :

Jika $d<d_{L}$ atau $d>4-d_{L}$, maka $H o$ ditolak yang berarti terdapat autokorelasi Jika $d>d_{U}$ atau $d<4-d_{U}$, maka $H o$ diterima yang berarti tidak terdapat autokorelasi.
Jika $d_{L}=d=d_{U}$ atau $4-d_{U}=d=$ $4-d_{L}$ maka pengujian tidak meyakinkan karena terdapat pada daerah keragu-raguan.

\section{Uji Hesteroskedastisitas}

Homoskedastisitas (varian sama) merupakan fenomena dimana pada nilai variabel bebas tertentu yang dipilih atau ditetapkan masing-masing kesalahan $\left(\boldsymbol{e}_{\boldsymbol{i}}\right)$ memiliki nilai varian yang sama, yaitu sebesar $\sigma^{2}$, Jika model regresi yang diperoleh ternyata tidak memenuhi asumsi maka terjadi heterokedastisitas yang mengakibatkan nilai-nilai estimator (koefisien regresi) dari model regresi tersebut tidak efisien meskipun estimator tersebut tidak bias dan konsisten (Gujarati, 1995).

Dalam penelitian ini pengujian terhadap adanya fenomena heterokedastisitas dilakukan dengan menggunakan uji Glejser dengan meregres nilai absolut residual terhadap variabel bebas.

\section{Uji Multikolinearitas}

Multikolinearitas merupakan fenomena adanya korelasi yang sempurna antara satu variabel bebas dengan variabel bebas lainnya. Beberapa konsekuensi yang timbul sebagai akibat adanya multikolinearitas ini adalah kesalahan standar penaksir semakin besar dan probabilitas untuk menerima hipotesis yang salah menjadi semakin besar (Gujarati, 1995).

Pengujian terhadap ada tidaknya multikolinearitas dilakukan dengan menggunakan metode Variance Inflation Factor (VIF) Gujarati, 1995). Kriteria yang dipakai adalah jika VIF > 10 berarti terjadi multikolinearitas tinggi antara regresor (variabel bebas) dengan regresor (variabel bebas lainnya).

Analisis regresi digunakan dalam bentuk regresi sederhana dan regresi ganda. Analisis regresi sederhana digunakan untuk mengetahui pengaruh variabel bebas (penilaian prestasi kerja, kepemimpinan, pendidikan, masa dinas dan jenjang pekerjaan) secara parsial terhadap variabel terikat ( produktivitas kerja karyawan). 
Analisis regresi ganda digunakan untuk mengetahui pengaruh semua variabel bebas secara bersama-sama terhadap variabel terikat. Untuk keperluan tersebut digunakan bantuan komputer dengan program SPSS . Secara statistik, formulasi regresi adalah sebagai berikut :

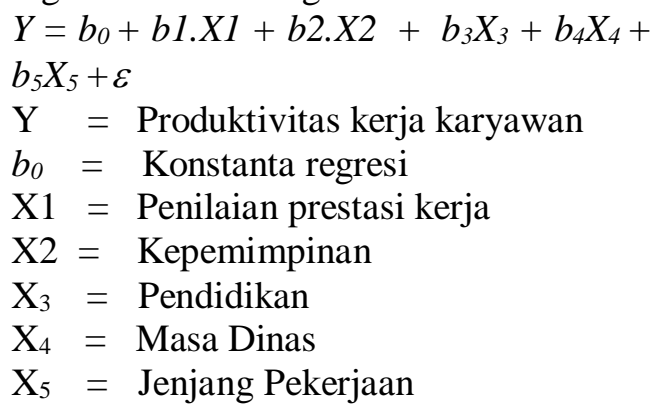

Tabel 1. Hasil Uji Reliabilitas Butir Pertanyaan

\begin{tabular}{lccc}
\hline \multicolumn{1}{c}{ Variabel Penelitian } & $\begin{array}{c}\text { Koef. } \\
\text { Reliabilitas }(\alpha)\end{array}$ & Koef. $\left(\mathrm{r}_{\text {Tabel }}\right)$ & Hasil \\
\hline Penilaian prestasi & 0,8636 & 0,1348 & Reliabel \\
Kepemimpinan & 0,8285 & 0,1348 & Reliabel \\
Produktivitas Kerja & 0,8230 & 0,1348 & Reliabel \\
\hline
\end{tabular}

Sumber :Data diolah

Hasil analisis regresi berganda dengan bantuan program SPSS diperoleh hasil regresi seperti diringkas dalam Tabel 2. berikut ini :

Tabel 2. Ringkasan Hasil Analisis Regresi Ganda

\begin{tabular}{cccc}
\hline Variabel & Koefisien & $\mathrm{t}_{\text {hitung. }}$ & Signifikansi \\
Independen $\left(\mathrm{X}_{\mathrm{i}}\right)$ & Regresi $\left(\mathrm{b}_{\mathrm{i}}\right)$ & $-9,301$ & 0,000 \\
Konstanta & $-2,309$ & 20,744 & 0,000 \\
Penilaian Prestasi & 0,963 & 20,897 & 0,000 \\
Kepemimpinan & 0,538 & 1,849 & 0,068 \\
Pendidikan & 0,009 & 1,672 & 0,098 \\
Masa Dinas & 0,011 & 0,785 & 0,434 \\
Jenjang Pekerjaan & 0,010 &
\end{tabular}

Koef. Determinasi $\left(\mathrm{R}^{2}\right)=0,887$

$\mathrm{F}_{\text {hitung }}=141,856$

Statistik DW = 2,064

$$
\mathrm{F}_{\text {Tabel }}=2,4707
$$

$\mathrm{t}_{\text {Tabel }}=1,6620$
Sumber : Data diolah

Dari hasil ringkasan analisis regresi ganda di atas, dapat dibuat model pengaruh variabel independen penilaian prestasi kerja (X1), kepemimpinan (X2), pendidikan (X3), masa dinas (X4) dan jenjang pekerjaan (X5) terhadap produktivitas kerja karyawan dengan model regresi sebagai berikut :

$\mathrm{Y}=-2,309+0,963 \mathrm{X}_{1}+0,538 \mathrm{X}_{2}+$ $0,009 X_{3}+0,011 X_{4}+0,010 X_{5}$

Pengaruh kelima variabel independen terhadap produktivitas kerja karyawan dengan cara mengukur koefisien regresi. Kalau nilai koefisien regresi bernilai positif berarti mempunyai pengaruh yang positif dan kalau nilai koefisien regresinya bernilai negatif berarti mempunyai pengaruh pengaruh yang negatif. Analisis model regresi tersebut digunakan untuk mengetahui tidak terjadi heteroskedastisitas, tidak terjadi autokorelasi, dan tidak terjadi multikolinearitas. Menguji ada tidaknya multikolinearitas dilakukan dengan menggunakan metode VIF (Variance Inflation Factor). Kriteria yang digunakan dalam pengujian VIF ini adalah sebagai berikut. Jika $V I F>10$ berarti 
terjadi multikolinearitas tinggi antara variabel independen (j) dengan variabel independen yang lain. Pengujian adanya multikolinearitas menggunakan program statistik SPSS dapat diringkas seperti dalam Tabel 3 berikut ini.

Tabel 3. Ringkasan Hasil Uji Multikolinearitas

\begin{tabular}{ccl}
\hline Variabel Independen & $\mathrm{VIF}_{\mathrm{j}}$ & Keterangan \\
\hline Penilaian Prestasi & 1,113 & multikolinearitas tidak terjadi \\
Kepemimpinan & 1,128 & multikolinearitas tidak terjadi \\
Pendidikan & 1,179 & multikolinearitas tidak terjadi \\
Masa Dinas & 1,070 & multikolinearitas tidak terjadi \\
Jenjang Pekerjaan & 1,183 & multikolinearitas tidak terjadi \\
\hline
\end{tabular}

Sumber : Data diolah

Hasil pengujian di atas, ternyata masing-masing variabel independen yang terdapat dalam model regresi tidak mengalami gejala multikolinearitas, dengan kata lain tidak melanggar uji asumsi .

Berdasarkan hasil perhitungan dengan menggunakan program SPSS, diperoleh nilai (d) atau DW $=2,064$. Dengan jumlah observasi $\mathrm{N}=96$ dan variabel independen $\left(\mathrm{k}^{\prime}\right)=5$, diperoleh nilai $\mathrm{dL}$ $=1,56$ dan nilai $\mathrm{dU}=1,78$.

Berdasarkan hasil analisis regresi yang telah dilakukan dengan bantuan program statistik SPSS. Diketahui bahwa besarnya $F_{\text {hitung }}=141,856$. Dengan derajad bebas pembilang $=5$, dan derajad bebas penyebut $=90$ pada tingkat singnifikansi $\alpha=5 \%$, dalam Tabel distribusi $\mathrm{F}$ diperoleh nilai $\mathrm{F}_{\text {Tabel }}=2,3157$. Jika kedua nilai $\quad \mathrm{F}$ hitung dan $\mathrm{F}$ Tabel tersebut dibandingkan ternyata $\mathrm{F}$ hitung lebih besar dari $\left.F_{\text {Tabel }}(141,856>2,3157)\right)$.

Hasil perbandingan ini membuktikan bahwa hipotesis nol (Ho) yang mengatakan secara simultan tidak ada pengaruh variabel independen harus ditolak. Penolakan hipotesis ini mengartikan bahwa hipotesis alternatif (Ha) yang menyatakan secara simultan ada pengaruh variabel independen harus diterima. Hasil pengujian hipotesis ini membuktikan bahwa pada tingkat kepercayaan 95\%, secara simultan berpengaruh signifikan. Besarnya pengaruh variabel independen tersebut ditunjukkan pula oleh nilai koefisien determinasi $\mathrm{R}^{2}$ yang dihasilkan sebesar 0,887 . Nilai koefisien determinasi membuktikan bahwa $88,7 \%$ produktivitas kerja karyawan PT. Centralpertiwi Bahari Feed Mill Operation ditentukan oleh variabel independen, 11,3\% produktivitas kerja karyawan PT. Centralpertiwi Bahari Feed Mill Operation ditentukan oleh faktor lain, dalam penelitian ini tidak dijadikan sebagai variabel penelitian. Besarnya koefisien determinasi $\mathrm{R}^{2}$ ini membuktikan pula bahwa kelima variabel independen memiliki keikatan yang sangat kuat, hasil perhitungan menunjukkan mendekati angka 1 sehingga dapat diartikan bahwa terdapat hubungan yang kuat antara produktivitas kerja dengan penilaian prestasi kerja, kepemimpinan, pendidikan, masa dinas dan jenjang pekerjaan.

\section{Penilaian Prestasi Kerja}

Secara parsial penilaian prestasi kerja mempengaruhi produktivitas kerja karyawan PT. Centralpertiwi Bahari Feed Mill Operation dilaksanakan dengan cara uji-t. Jika dalam uji-t tersebut menghasilkan nilai t-hitung lebih besar dari nilai t-Tabel, maka secara parsial penilaian prestasi kerja mempengaruhi secara signifikan terhadap produktivitas kerja karyawan. Sebaliknya, jika nilai thitung lebih kecil dari nilai t-Tabel, maka secara parsial penilaian prestasi kerja tidak mempengaruhi secara signifikan terhadap produktivitas kerja karyawan.

Perhitungan dan hasil analisis regresi yang dirangkum dalam Tabel 2 di atas dapat dilihat bahwa nilai t-hitung yang diperoleh sebesar 20,744. Sedangkan nilai t-Tabel dengan derajad bebas (df) sebesar 90 pada tingkat signifikansi $\alpha=5 \%$, dari Tabel distribusi nilai $t$ diperoleh nilai $t$ Tabel 1,6620. Hasil uji-t yang 
menyatakan secara parsial tidak ada pengaruh signifikan dari variabel penilaian prestasi kerja terhadap produktivitas kerja karyawan PT. Centralpertiwi Bahari Feed Mill Operation harus ditolak. Penolakan ini membuktikan pula bahwa hipotesis alternatif (Ha) yang menyatakan secara parsial ada pengaruh signifikan dari variabel penilaian prestasi karja terhadap produktivitas kerja karyawan PT. Centralpertiwi Bahari Feed Mill Operation harus diterima.

Pengujian hipotesis secara masing-masing dengan uji-t pada tingkat kepercayaan 95\% penilaian prestasi kerja mempengaruhi secara signifikan produktivitas kerja karyawan PT. Centralpertiwi Bahari Feed Mill Operation. Hasil ini membuktikan bahwa para karyawan PT. Centralpertiwi Bahari Feed Mill Operation memiliki produktivitas kerja terhadap hasil penilaian prestasi kerja yang dilakukan PT. Centralpertiwi Bahari Feed Mill Operation. Hal ini didukung pula oleh analisis deskriptif yang menyatakan bahwa karyawan menganggap penilaian prestasi kerja karyawan berada pada kategori sangat baik $(85,34 \%)$ dan karyawan menganggap produktivitas kerja karyawan berada pada kategori baik $(76,17 \%)$. Meskipun kedua nilai tersebut belum mencapai nilai maksimum, tapi produktivitas kerja karyawan PT. Centralpertiwi Bahari Feed Mill Operation secara signifikan dipengaruhi oleh adanya penilaian prestasi kerja yang dilakukan oleh PT. Centralpertiwi Bahari Feed Mill Operation. Signifikansi penilaian prestasi kerja mempengaruhi produktivitas kerja karyawan ini membuktikan pula bahwa penilaian prestasi kerja menimbulkan produktivitas hipotesis alternatif $(\mathrm{Ha})$ yang menyatakan secara parsial ada pengaruh signifikan dari variabel kepemimpinan terhadap produktivitas kerja karyawan PT. Centralpertiwi Bahari Feed Mill Operation harus diterima.

Pengujian hipotesis masing-masing dengan uji t ini dapat disimpulkan kerja karyawan yang lebih baik. Penilaian prestasi kerja yang baik berarti karyawan PT. Centralpertiwi Bahari Feed Mill Operation dapat memahami sistem penilaian prestasi, menganggap penilaian tersebut cukup objektif, tidak terjadi distorsi, dijadikan dasar keputusan penetapan karyawan dan pengembangan karir karyawan.

\section{Kepemimpinan}

Secara parsial kepemimpinan mempengaruhi produktivitas kerja karyawan PT. Centralpertiwi Bahari Feed Mill Operation dilaksanakan dengan cara uji-t. Jika dalam uji-t tersebut menghasilkan nilai t-hitung lebih besar dari nilai t-Tabel, maka secara parsial kepemimpinan mempengaruhi secara signifikan terhadap produktivitas kerja karyawan. Sebaliknya, jika nilai t-hitung lebih kecil dari nilai t-Tabel, maka secara parsial kepemimpinan tidak mempengaruhi secara signifikan terhadap produktivitas kerja karyawan.Perhitungan dan hasil analisis regresi yang dirangkum dalam Tabel 2 di atas dapat dilihat bahwa nilai t-hitung yang diperoleh sebesar 20,897. Sedangkan nilai t Tabel dengan derajat bebas (df) sebesar 90 pada tingkat signifikan $\alpha=5 \%$, dari Tabel distribusi nilai t diperoleh nilai t Tabel 1,6620. Jika kedua nilai $\mathrm{t}$ hitung dan nilai $\mathrm{t}$ Tabel tersebut dibandingkan diperoleh nilai $\mathrm{t}$ hitung lebih besar dari t Tabel (20,897 > 1,6620). Hasil uji $\mathrm{t}$ ini membuktikan bahwa hipotesis nihil (Ho) yang menyatakan secara parsial tidak ada pengaruh signifikan dari variabel

kepemimpinan terhadap produktivitas kerja karyawan PT. Centralpertiwi Bahari Feed Mill Operation harus ditolak. Penolakan ini membuktikan pula bahwa

bahwa pada tingkat kepercayaan 95\% , kepemimpinan mempengaruhi secara signifikan pada produktivitas kerja karyawan PT. Centralpertiwi Bahari Feed Mill Operation. Signifikansi kepemimpinan mempengaruhi produktivitas kerja karyawan terbukti pula bahwa kepemimpinan menimbulkan produktivitas kerja karyawan dan 
produktivitas kerja karyawan yang lebih tinggi dihasilkan pula oleh kepemimpinan yang lebih tinggi pula.

\section{Tingkat Pendidikan Karyawan}

Secara parsial tingkat pendidikan mempengaruhi produktivitas kerja karyawan PT. Centralpertiwi Bahari Feed Mill Operation dilaksanakan dengan cara uji-t. Jika dalam uji-t tersebut menghasilkan nilai t-hitung lebih besar dari nilai t-Tabel, maka secara parsial tingkat pendidikan mempengaruhi secara signifikan terhadap produktivitas kerja karyawan. Sebaliknya, jika nilai t-hitung lebih kecil dari nilai t-Tabel, maka secara parsial tingkat pendidikan tidak mempengaruhi secara signifikan terhadap produktivitas kerja karyawan.

Perhitungan dan hasil analisis regresi yang dirangkum dalam Tabel 2 di atas dapat dilihat bahwa nilai t-hitung yang diperoleh sebesar 1,849 . Sedangkan nilai t Tabel dengan derajat bebas (df) sebesar 90 pada tingkat signifikan $\alpha=5 \%$, dari Tabel distribusi nilai $\mathrm{t}$ diperoleh nilai $\mathrm{t}$ Tabel 1,6620. Pengujian hipotesis secara parsial dengan uji t ini dapat disimpulkan bahwa pada tingkat kepercayaan 95\%, tingkat pendidikan mempengaruhi secara signifikan pada produktivitas kerja karyawan PT. Centralpertiwi Bahari.

\section{Masa Dinas Karyawan}

Secara parsial masa dinas mempengaruhi produktivitas kerja karyawan PT. Centralpertiwi Bahari Feed Mill Operation dilaksanakan dengan cara uji-t. Jika dalam uji-t tersebut menghasilkan nilai t-hitung lebih besar dari nilai t-Tabel, maka secara parsial masa dinas mempengaruhi secara signifikan terhadap produktivitas kerja karyawan. Sebaliknya, jika nilai t-hitung lebih kecil dari nilai t-Tabel, maka secara parsial masa dinas tidak mempengaruhi pekerjaan terhadap produktivitas kerja karyawan PT. Centralpertiwi Bahari harus diterima. Penerimaan ini membuktikan pula bahwa hipotesis alternatif (Ha) yang menyatakan secara parsial ada pengaruh signifikan dari variabel jenjang pekerjaan terhadap produktivitas kerja karyawan PT. Centralpertiwi Bahari harus ditolak. secara signifikan terhadap produktivitas kerja karyawan. Perhitungan dan hasil analisis regresi yang dirangkum dalam Tabel 2 di atas dapat dilihat bahwa nilai thitung yang diperoleh sebesar 1,672. Sedangkan nilai t Tabel dengan derajat bebas (df) sebesar 90 pada tingkat signifikan $\alpha=5 \%$, dari Tabel distribusi nilai $\mathrm{t}$ diperoleh nilai t Tabel 1,6620.

Pengujian hipotesis masing-masing dengan uji t tersebut disimpulkan bahwa pada tingkat kepercayaan 95\%, masa dinas mempengaruhi secara signifikan pada produktivitas kerja karyawan PT, Centralpertiwi Bahari.

\section{Jenjang Pekerjaan Karyawan}

Secara parsial jenjang pekerjaan mempengaruhi produktivitas kerja karyawan PT. Centralpertiwi Bahari Feed Mill Operation dilaksanakan dengan cara uji-t. Jika dalam uji-t tersebut menghasilkan nilai t-hitung lebih besar dari nilai t-Tabel, maka secara parsial jenjang pekerjaan mempengaruhi secara signifikan terhadap produktivitas kerja karyawan. Sebaliknya, jika nilai t-hitung lebih kecil dari nilai t-Tabel, maka secara parsial jenjang pekerjaan tidak mempengaruhi secara signifikan terhadap produktivitas kerja karyawan. Perhitungan dan hasil analisis regresi yang dirangkum dalam Tabel 2 di atas dapat dilihat bahwa nilai t-hitung yang diperoleh sebesar 0,785 . Sedangkan nilai t Tabel dengan derajat bebas (df) sebesar 90 pada tingkat signifikan $\alpha=5 \%$, dari Tabel distribusi nilai $\mathrm{t}$ diperoleh nilai $\mathrm{t}$ Tabel 1,6620. Jika kedua nilai t hitung dan nilai $\mathrm{t}$ Tabel tersebut dibandingkan diperoleh nilai t hitung lebih besar dari t Tabel $(0,785<1,6620)$. Hasil uji $\mathrm{t}$ ini membuktikan bahwa hipotesis nihil (Ho) yang menyatakan secara parsial tidak ada pengaruh signifikan dari variabel jenjang Pengujian hipotesis secara masing-masing dengan uji-t pada tingkat kepercayaan 95\%, jenjang pekerjaan mempengaruhi secara signifikan produktivitas kerja karyawan PT. Centralpertiwi Bahari Feed Mill Operation.

\section{Pengaruh Dominan}




\begin{abstract}
Faktor dominan yang mempengaruhi produktivitas kerja karyawan PT. Centralpertiwi Bahari Feed Mill Operation adalah penilaian prestasi kerja yang ditunjukkan nilai koefisien regresi variabel penilaian prestasi kerja sebesar 0,963, lebih besar dari pada nilai koefisien regresi variabel kepemimpinan sebesar 0,538, lebih besar dari nilai koefisien regresi variabel masa dinas sebesar 0,011, lebih besar dari nilai koefisien regresi variabel jenjang pekerjaan sebesar 0,010 , dan lebih lebih besar dari nilai koefisien regresi variabel pendidikan sebesar 0,009. Berdasarkan hasil perhitungan, masing-masing faktor memberikan kontribusi pengaruh terhadap produktivitas kerja karyawan. Dengan melihat nilai koefisien tersebut faktor penilaian prestasi kerja yang paling mempengaruhi secara dominan pada produktivitas kerja karyawan PT. Centralpertiwi Bahari Feed Mill Operation. Hal ini sekaligus menunjukkan bahwa kepemimpinan masih belum berjalan sebagaimana yang diharapkan dan perlu adanya perbaikanperbaikan guna memberikan kontribusi pada produktivitas kerja karyawan.
\end{abstract}

\section{Kesimpulan dan Saran :}

Hasil pengumpulan dan pengolahan data serta pembahasan yang telah dilakukan, maka dapat disimpulkan sebagai berikut :

1. Faktor produktivitas kerja karyawan PT. Centralpertiwi Bahari dipengaruhi oleh penilaian prestasi kerja, kepemimpinan, pendidikan, masa dinas dan jenjang pekerjaan secara simultan positif.

2.Faktor penilaian prestasi kerja mempengaruhi produktivitas kerja karyawan PT. Centralpertiwi Bahari Feed Mill Operation secara dominan dibandingkan dengan faktor lainnya.

\section{Saran :}

1. Pemimpin PT. Centralpertiwi Bahari Feed Mill Operation hendaknya tetap menjadikan penilaian prestasi kerja sebagai dasar keputusan, memberikan penilaian prestasi kerja secara obyektif, memberikan insentif kepada karyawan dan memberikan penghargaan secara adil serta memberikan berbagai fasilitas kepada karyawan sesuai dengan pendidikan dan masa dinas mereka agar prestasi karyawan meningkat sejalan dengan peningkatan produktivitas kerja.

2.Pemerintah Kabupaten Lampung Selatan atau Propinsi Lampung perlu menetapkan indeks dasar produktivitas secara umum dalam agroindustri, khususnya dalam pakan udang.

3.Bagi karyawan agar selalu meningkatkan produktivitasnya, terutama dalam menjalankan penilaian prestasi kerja. 4. Sebaiknya perusahann menetapkan visi dan missi yang jelas, khususnya yang berorientasi pada peningkatan produktivitas kerja melalui kompensasi. Sedangkan kebijakan jangka panjang lebih berorientasi pada usaha peningkatan kualitas sumber daya manusia.

\section{Daftar Pustaka}

Amin, W. Dan J. Suryono. (2017), Analisis Pengaruh Gaya Kepemimpinan, Motivasi dan Lingkungan Kerja Terhadap Produktivitas Pegawai Kantor Komunikasi Kehumasan Boyolali, Jurnal Manajemen Sumber Daya Manusia 1.1:1-17.

Anwar Nurdin, M. R. (2019), Pengaruh Kepemimpinan Dan Pelatihan Terhadap Kinerja Karyawan Bank DKI Jakarta, Jurnal Manajemen Bisnis Krisnadwipayana 7.2:96-103.

Apriliani, N. (2018), Analisis Pengaruh Gaya Kepemimpinan, Motivasi Dan Lingkungan Kerja Terhadap Produktivitas Karyawan CV. Sahabat Klaten , Skripsi, Universitas Muhammadiyah Surakarta Fakultas Ekonomi dan Bisnis Program Studi Akuntansi 1.1:1-25.

Diastuti, W. J. (2014), Pengaruh Gaya Kepemimpinan Dan Kepuasan Kerja Terhadap Kinerja Karyawan, Studi Kasus PT Sarinah (Persero) Jakarta Woro, Jurnal MIX, IV.1.:114-122.

Ghozali, Imam. (2018), Aplikasi Analisis Multivariate Dengan Program SPSS. Cetakan Kesembilan. Semarang, Badan Penerbit Universitas Diponegoro.

Gary Desler, (2006), Manajemen Sumber 
Daya Manusia, Diterjemahkan oleh Eli Tanya, Gramedia, Jakarta.

Gosyen Publishing Ishaya, Salis R. (2017),

Pengaruh Motivasi Terhadap Produktivitas Kerja Karyawan Pada PT. Arka Mahesa Pratama di Jakarta Selatan, Jurnal Lentera Bisnis. 6.2: 94-107.

Handoko, T. Hani.(2014), Manajemen Personalia dan Sumber Daya Manusia, Yogyakarta, BPFE.

Jatmiko, D. E. dan B. Swasto. (2018),

Pengaruh Motivasi Kerja Dan Gaya Kepemimpinan

Terhadap Produktivitas Karyawan Pada PT. Petrokimia Gresik. Jurnal Administrasi Bisnis (JAB) 21.2:1-34.

Hasyim, P., \& Nuridin, N. (2020), Pengaruh Kepemimpinan Dan Budaya Organisasi Terhadap Kinerja Karyawan PT. Kao Indonesia, Jurnal Manajemen Bisnis Krisnadwipayana, 8.2:44-56.

Kasmir. (2016), Manajemen Sumber Daya Manusia (Teori dan Praktik). Jakarta, PT Raja Grafindo Persada.
Malik, S. Z., Saleem, M., \& Naeem, R. (2016), Effect of leadership styles on organizational citizenship behaviour in employees of telom sector in Pakistan. Pakistan Economic and Social Review, 54.2:385-406.

Rahmisyari. (2015), Effect of Leadership Styles, Organizational Culture and Employees Development on Performance (Studies in PT. PG. Gorontalo of Tolangohula Unit), International Journal of Business and Management Invention, 4.1: 8591.

Windarwati, D., Payangan, O. R., \& Hamid, N. (2016), Pengaruh budaya organisasi dan gaya kepemimpinan terhadap komitmen karyawan pada PT. Perkebunan Nusantara XIV. Jurnal Analisis, 5.1:96-102.

Zainal, R. Veithzal dkk, (2014), Kepemimpinan dan Perilaku Organisasi, Jakarta, PT Raja Grafindo Persada 